while in every case this mode of treatment facilitated and expedited the healing action in the injured, it may be lacerated, parts. I dwell at length on this case, as it is a characteristic one as regards the treatment I recommend, and undoubtedly seemed a peculiarly hopeless one. I can only add, therefore, that none need despair after the recovery of this case and the harmlessness of the operation of suction. Without doubt it is always better for the person bitten to suck the wound himself; when this is impossible, as in the case of the gardener, then the act of suction can be safely done by others, if the precautions taken in the case of the gardener's brother are carefully carried out.

During my thirty years' service in India, being very fond of dogs, $I$ had not only a considerable number, but also a great variety, and among them only two cases of hydrophobia occurred: one, the case of the terrier which bit me, and the other that of a well-bred spaniel, which I used for pheasant shooting in the Himalayas. The case of the former exhibits the treatment I recommend, and that of the latter the mode of preventing the disease spreading. These two dogs illustrate also the very opposite symptoms as regards their behaviour to their master. The terrier, my pet dog, without any cause or warning other than sulking for a little time, rushed at me and bit me; the spaniel, my sporting companion, passed me on the road, as if it wished to avoid me. I at once felt something must be wrong with the dog, and on my return home the servants told me it was missing. On looking for it near the house, I saw it lying in the shade of a bush, gasping, in a condition of fully developed rabies, and, getting a gun, I shot it at once, before it had started on its mad race and bitten, and thus infected, either man or beast.

Now I would close with a word or two regarding what seems to me the cause of the present epidemic of rabies and the mode of stamping it out. Though nothing but the virus of rabies can produce rabies, yet when segregation favours the spread of the disease, as is the case now, an epidemic quickly results. My Indian experience has satisfied me that if the subjects likely to be affected are limited, the tendency of the disease is to die out, otherwise rabies would be an alarmingly common disease in that country, whereas it is, everything considered, a rare disease. Rabies, without doubt, is a disease due to a special virus, and not to conditions of living or food, otherwise I should have seen numbers of cases of the disease among the dogs and jackals at Juggernauth, where, at certain periods of the year, the food of these animals used to be human corpses, generally the victims of cholera, and little else, and yet among these dogs and jackals in their natural state I never saw a single case of the disease in four years. Thusit will be possible to stamp out the disease, not by removal of the conditions credited (?) with the production of the disease (as if they exist they are unknown further than the insertion of the virus), but by the reduction of the causes which propagate it, and which have lately increased to an extent which would have been incredible had not the results of the late police action told in unmistakable terms what a "plague of dogs" we have been suffering from. One case of rabies till very lately had the power of propagating the disease to an extent which was impossible thirty or forty years ago. Let us, therefore, aim at reducing the number of uncared-for dogs to be met with by a dog suffering from rabies, and we shall then reduce the cases of the disease, till the last mad dog is put an end to, before it has spread the contagion; but this can never be the case with such numbers of uncared-for dogs about. The owner of a dog exhibiting suspicious symptoms should be obliged to place it under supervision, or be answerable for it, so that if rabies is developed, while under this supervision the dog may be destroyed and the possibility of that characteristic symptom of hydrophobia, the mad-dog race, which is the most fertile source of the dissemination of the contagion, effectually prevented.

Blackheath, S.E.

A FEw days ago a beautiful obelisk of red granite, erected by a few friends to the memory of the late Dr. Alexander Hogg, of Workington, in the new cemetery of that town, was unveiled with appropriate ceremony. Dr. Hogg was medical officer of health for the town, and during his short but successful practice of four years and a half endeared himself to all. He died on Nov. 2nd, 1883, while on a visit to his father's house, Larbert, Stirlingshire, at the early age of twenty-six years.

\section{A CASE OF DELIRIUM TREMENS CAUSED BY CHEWING TEA.}

BY W. B. SLAYTER, M.D., L.R.C.P. LOND., M.R.C.S. ENG., LATE CONSULTING SURGEON, PROVINCTAL AND CITY HOSPTTAI, HALIFAX, NOVA SCOTIA.

ON November 10 th, 1879 , I was summoned by a lady to see her female servant. The girl complained of sleeplessness, nervousness, and repeated twitchings of the muscles of the face and extremities, which would continue for several minutes at a time. These symptoms had been present for several months previously. Her mistress informed me that. the girl had been acting strangely for several days. She was wandering in her mind at times, and imagined people and evil spirits were about her seeking to do her harm. She had not slept for several nights, and on one or two occasions had been found at night wandering about the house. Pulse 96 and small; tongue dry and brown; eyes suffused; irregular action of the heart-weight at præcordia; sallow complexion. A dose of bromide of potassium and hydrate of chloral gave her a good rest for the night, and next morning she was sent home to her mother.

At $4.30 \mathrm{~A} . \mathrm{Mr}$. on the 13th I was again summoned to see her. Some men had found her walking about one of the wharves of our city, in the neighbourhood of her mother's house. They tried to persuade her to go home, but she broke away from them and endeavoured to jump off the end of the wharf, when she was caught and taken to her home. I found her with a pulse of $110^{\circ}$, a very dry and brown tongue, suffused eyes, no marked increase of temperature, violent delirium, and tremulous hands and arms-in short, the well-marked symptoms of delirium tremens. Her mother informed me that she had complained of a good deal of pain in the abdomen, and on examination I found a smooth, quite hard tumour in the right iliac region, half as large again as an ordinary orange. Owing to the violent delirium I was unable to find out whether it was tender to the touch or not. A hypodermic injection of morphia somewhat relieved the nervous symptoms. A brisk cathartic brought away a mass of hardened fæces, followed by a large quantity of a thickish tarry-looking excreta, which seemed to be made up of tea-leaves in different stages of maceration, quite a large proportion, probably a third, being tea-leaves quite unchanged in appearance or colour. Bromide of potassium and chloral in a few days quieted the nervecentres; good nursing, proper diet, and tonics soon restored the patient to her usual health. After the action of the cathartic I found the abdominal swelling somewhat lessened in size, but it was not until several doses at intervals had been administered that the tumour entirely disappeared. After each dose a quantity of tea-leaves were expelled. In about three weeks the evacuations were normal in appearance, and her general health was fairly restored.

I had lost sight of this patient until October last, when I was once more summoned to see her. It is not necessary to again enter on a history of the case. The same well-marked symptoms of delirium tremens were present; there was no tumour to be found, but the evacuations contained a plentiful supply of tea-leaves. The same course of treatment soon restored her to health, and I trust a longer continuance of tonics and building-up treatment may succeed in preventing a recurrence of the symptoms. The patient informed me that when about seventeen years of age she went to one of the New England towns to work in a factory, and there contracted the habit of chewing tea-a habit, she stated, quite common amongst the factory girls. She thought she chewed on an average about half a pound of tea daily, and some days more. It made her feel better able to work. Of course, as to quantity her estimate may not be depended on. She had never been addicted to alcoholism, and ascribed her attacks solely to the tea-chewing. She tried to give it up, but felt so nervous and fidgety as to be compelled to return to the old habit. This second attack caused me to copy from my case-book the notes taken at the time. The only points of importance are the cause and the repeated and continuous muscular twitchings. Of course most physicians have met with many cases of great nervousness and fidgetiness occasioned by excessive tea-drinking, but $I$ cannot find any record in any of the works on medicine or materia medica within my reach of such severe symptoms being induced by tea-chewing. Ringer tells us that "the 
Physiological Committee presided over by the late Dr. Hughes Bennett concluded that the motor nerves are unaffected." The long-continued repeated muscular twitchings would seem to contradict this portion of the committee's report.

\section{ROTHELN: A POINT OF DIAGNOSIS.}

\section{BY JAMES GREY GLOVER, M.D.}

THe extreme infectiousness, notwithstanding the comparative harmlessness, of German measles makes it very desirable to find early indications of its presence. I have been struck lately in two or three cases with the fact that the earliest symptom to excite the notice of the patient has been a swollen gland in the neck at the back of the sterno-mastoid muscle. One young lady lately consulted me about such a gland of a considerable size, and without any obvious explanation in its neighbourhood. Four days later the rash of Rotheln appeared and explained the mystery, and the single gland had become the usual chain on both sides of the neck. When the disease is prevalent, or already exists in a family, and a swollen cervical gland in a young person appears without obvious reason, it may be suspected that the disease is already in the system. The occurrence of cervical glandular enlargements is of course one of the commonest and most interesting notes of this least pyrexial of the eruptive diseases, and the early appearance of the symptom coincidently with the rash, or even a day before, as Dr. Goodhart describes in one case, is also known. But its appearance four or tive days before the eruption seems worth noting for diagnostic purposes.

Highbury-place, $\mathrm{N}$.

\section{A}

of

\section{HOSPITAL PRACTICE, BRITISH AND FOREIGN.}

Nulla autem est alia pro certo noscendi via, nisi quamplurimas et morborum et dissectionum historias, tum aliorum tum proprias collectas sabere, et inter se comparare.-MoRGaGi De $\$$ Ed. et Caus. Morb. vabere, et inter se
lib. iv. Procemium.

SEAMEN'S HOSPITAL, GREENWIOH.

ULCERATIVE ENDOCARDITIS; ANOMALOUS SKIN ERUPTION; INTESTINAL ULCERATION; DEATH; NECROPSY.

(Under the care of Dr. CURNow.)

DURING the last few months, especially since the delivery at the Royal College of Physicians of the lectures on Malignant Endocarditis, we have published several cases of ulcerative endocarditis, but none of them have presented the unusual features of the following case, which is well worthy of record. The difficulty of diagnosing the exact cause of the disease in the absence of evidence of cardiac mischief was insuperable. We are indebted for the following notes to Mr. E. H. Booth, M.B., house-physician.

James K - , aged forty-five, was admitted on March $12 \mathrm{th}$, 1886. On examination his condition was found to be as follows: He was lying deep down in the bed; face flushed; pupils dilated; excited and delirious - so much so that all attempts to procure a history failed. His tongue was rather enlarged, red, dry, and glazed. Temperature $1035^{\circ}$; pulse 120 , very weak and fluttering. Decided oedema of feet and ankle; effusion in both knee-joints; well-marked purpuric rash on both legs, mostly on the inner sides; purpuric blotches on the inner side of the thighs, and a few purpuric spots on the front of the thighs. There were erythematous patches with petechiæe over the parts exposed to pressurei.e., over both hips, shoulders, and elbows. There were a few livid red patches over some of the joints of the hands. A few petechiæe were scattered over the surface of the abdomen and chest, also a few spots, looking very much like typhoid spots in character. IIis abdomen was distended and tumid; resonant all over. During the first night he was in the hospital he passed a very loose stool, greenish, and tinged also with a little blood. Heart listened to very care- fully; beating rapidly, and sounds very feeble; no bruit to be heard. Chest resonant all over: moist sounds at both bases; no other physical signs. Urine very acid; sp. gr. 1026; loaded with albumen; deposit of urates; no blood or casts.

It was thought that the patient might be suffering either from pyæmia or severe typhoid. He was given five grains of quinine every four hours, and twelve ounces of brandy were ordered. His temperature, taken every two hours, kept between $103^{\circ}$ and $104^{\circ}$, in spite of wet packing. He gradually sank, and died on the night of the 13th.

Post-mortem examination.-A good deal of cadaveric lividity. Rigor mortis marked. Abdomen opened. The small intestines were rather distended; pale, but presenting at intervals patches of congestion pointing to ulceration. The intestines were opened up, and there were discovered about fifteen to twenty ulcers; the majority of these were round, with ragged edges; each ulcer was surrounded with a large patch of congestion; at one or two places the ulcers were longitudinal in direction, and occupied Peyer's patches. At a few other places were patches of congestion, and in the centre of each patch a small grey hard nodule about the size of a pin's head, and not unlike tubercle in appearance. Most of the ulcers were in the lower part of the ileum, but one or two small ulcers existed near the duodenum. Heart: Old pericarditis, there being dense adhesions over most of its surface; the pericardial cavity remaining contained a small quantity of semi-purulent matter; heart not enlarged; right side normal; aortic valves thickened, especially towards the edges; mitral valve thickened; along the edges was a continuous fringe of fine granulation and ulceration; at one spot the ulcer was about half the size of a threepenny piece. Kidneys enlarged, pale; capsules not adherent; all over the surface were seen a number of small yellow spots, each surrounded by a halo of congestion, each spot being a minute abscess; on section it was pale and dotted all over with minute abscesses and points of congestion. Spleen much enlarged; about three times the normal size; very soft and congested; no infarcts to be distinguished. Lungs very odematous and congested; almost black with congestion towards bases; no infarcts to be distinguished.

The case is of peculiar interest from the difficulty in arriving at a diagnosis, the anomalous character of the eruption, and the numerous ulcers in the intestines from infarcts carried from the diseased valves. It is most uncommon to find so many intestinal ulcers from this cause.

\section{ST. GEORGE'S AND ST. JAMES'S DISPENSARY.} CASE OF ERYTHEMTA NODOSUM; REMARKS. (Under the care of Dr. Francts Hawirins.)

MARY D-, aged thirty-five, married (no children), tailoress, born in London, was admitted on Aug. 30th, 1885, complaining of sore-throat, thirst, anorexia, and constipation. She had been ill about one day. Her father was a Pole. He died from abscess of the lung. Her mother, a Frenchwoman, died in an asylum. She has four sisters. Two are quite well and have never been ill. One older than herself had an illness (erythema nodosum) similar to her own four years ago. The other sister, also older than herself, had a fit four years ago; the medical attendant pronounced it epilepsy. She has had frequent repetitions of the fits, and last August was placed in an asylum, where she still remains. There is one brother quite well. There is no history of rheumatism ever having occurred in the family. Her home is comfortable. She works at her calling away from home. Eleven years ago (at the age of twenty-four) the patient had pains and swelling in the ankle-joints, and a few red painful spots on her legs. Her medical attendant informed her she had rheumatic fever, but she was up and about the whole time. From this attack she entirely recovered, and remained perfectly well until four years ago (at the age of thirtyone), when she felt weak and had sore-throat, for which she went as an out-patient to King's College Hospital. Three days after attending there she felt pains in her joints, and some spots came out on her legs, similar to the spots which came out seven years previously This time the spots came out on the arms as well as on the legs. (It was about this time that her sister also had pains in her joints and spots on her legs similar to those on the patient; her sister has never had a second attack.) From this she soon recovered, and continued quite well until the 30th of August, 1885, when 